\title{
Геннадий Эстрайх
}

(Нью-Йоркский университет, Нью-Йорк, США; НИУ ВШЭ, Москва, Россия)

Профессор, Отделение гебраистики и иудаики, Нью-Йоркский университет,

ведущий научный сотрудник, Международный центр истории и социологии Второй мировой войны и ее последствий, Национальный исследовательский университет

«Высшая школа экономики»

E-mail: ge293@nyu.edu

ID ORCID: 0000-0002-7885-7851

\section{Слухи о выселении в Биробиджан, Анастас Микоян и американский еврейский истеблишмент}

\begin{abstract}
Аннотация: Статья анализирует события 1958-го и 1959-го гг., когда проблема Биробиджана широко обсуждалась на Западе, в кругах еврейских деятелей. Связано это было со слухами о «смертельной опасности, грозящей советским евреям», которым правительство якобы уготовало массовое переселение на Дальний Восток, в Еврейскую автономную область. В январе 1959 г. представители Американского еврейского комитета встретились в Нью-Йорке с Анастасом Микояном, первым заместителем председателя Совета министров СССР. Микоян прибыл в США для проведения предварительных встреч в преддверии исторического визита Никиты Хрущева в сентябре 1959 г. Вопросы, связанные с положением евреев, не входили в повестку дня его визита. Тем не менее, столкнувшись с многочисленными вопросами о плане переселения евреев, он и его советники посчитали нужным встретиться с влиятельными фигурами американского истеблишмента. Статья анализирует обстоятельства этой встречи и ее след в советской еврейской истории.
\end{abstract}

Ключевые слова: Биробиджан, Микоян, Хрущев, антисемитизм, идиш, Шолом-Алейхем DOI: $10.31168 / 2658-3364.2018 .1 .2 .5$

В этой статье речь идет о коротком, но ключевом эпизоде в советской еврейской истории, началом которого стали откровения главы советского государства Н.С. Хрущева, вызвавшие возмущение в западных средствах массовой информации. Парадоксальным образом несколько неуместных фраз запустили цепную реакцию событий, в конечном итоге оказавших положительное влияние на состояние еврейской культуры в СССР. В силу стечения обстоятельств участником этих событий стал А.И. Микоян 
(1895-1978), по характеру своей деятельности не имевший прямого отношения к «еврейскому вопросу» в СССР.

\section{Интервью газете «Фигаро»}

Фраза «Хрущева понесло» встречается многократно в литературе об оттепельном периоде жизни в СССР. Понесло Никиту Сергеевича и тогда, когда он давал интервью парижской газете «Фигаро». Текст беседы, опубликованный 9 апреля 1958 г., вызвал в лучшем случае недоумение, а публицист и литературный критик Ирвинг Xay (Irving Howe, 1920-1993), заметная фигура среди американских социалистов, диагностировал у советского руководителя «вульгарный антисемитизм» [Norwood 2013, 185]. Действительно, в том злосчастном интервью Хрущев поделился своими мыслями о евреях. Оказалось, что они видятся ему кустарями или интеллектуалами, увиливающими от массовых профессий в строительстве и металлургии. Хау и другие наблюдательные читатели скорее всего не уделили бы особого внимания этому высказыванию, тем более что на самом деле и в строительстве, и в металлургии трудилось немало советских евреев (см., например, [Константинов 2007, 220]). Но Хрущев на этом не остановился и продолжил писать широкими мазками видевшуюся ему картину советской еврейской жизни. На этом полотне евреи предстали индивидуалистами, не желающими состоять в коллективе, подчиняться его дисциплине. Сказано это все было в качестве объяснения провала биробиджанского проекта: мол, поехали туда с энтузиазмом, но потом один за другим разбежались [Pinkus 1984, 62].

В текст интервью, напечатанный в советской прессе, эти размышления Первого секретаря ЦК КПСС и Председателя Совета Министров СССР не вошли. В версии, отфильтрованной агитпропом, Хрущев говорил об антиеврейских погромах в царской России и об их прекращении при советской власти [Известия 1958, 1-2]. Ничего не было сказано о разгроме всей, за исключением незначительных остатков в Биробиджане, инфраструктуры еврейской культурной и научной жизни в последние годы сталинского правления, о физическом уничтожении деятелей еврейской культуры и науки и о нежелании послесталинского руководства дать разрешение на восстановление разгромленного. Концерты еврейской песни и выступления нескольких любительских коллективов были практически единственными санкционированными формами культурной жизни на языке идиш [Эстрайх 2009, 106-126; Френкель 2016, 305-320]. Пережившим репрессии прозаикам и поэтам, не отказавшимся писать на идише, разрешалось продолжать это делать, но власти не разрешали печатать их произведения на языке оригинала - они могли увидеть свет только в переводе на русский или другие языки советских народов. Самые упрямые писатели печатались в комму- 
нистической еврейской периодике Польши, Франции и США, хотя и за такое самовольство можно было получить нагоняй [Эстрайх 2015, 257-260].

Ситуация с еврейской культурой и вообще с еврейской жизнью в СССР широко обсуждалась в западной печати. Слова Хрущева вызвали многочисленные комментарии. По мнению «Нью-Йорк таймс», «наделив евреев специфическими характерными особенностями, в частности, склонностью к вредным для жизни в коллективе интеллектуальным интересам, он выделил их в группу, особенно непригодную для нормальной жизни в советском обществе» [The New York Times 1958, 7]. На самом деле Хрущев высказал не только свое мнение. В 1957 г. Морис Торез, генеральный секретарь Французской компартии, узнал от своих московских коллег, что те считают евреев самым слабым звеном советского общества и что восстановление еврейской культуры, по их мнению, только усилит еврейский национализм [Эстрайх 2015, 263-264].

Характеристика, данная евреям советским руководителем, вызвала раздражение или даже гнев у редакторов газеты американских еврейских коммунистов «Моргн-фрайхайт». В ее редакционном комментарии смысл слов советского руководителя был назван «непостижимым» и «полностью оторванным от реальности». По мнению редакции, у правительства Хрущева отсутствовал «поддающийся пониманию подход к еврейскому вопросу». После ХХ съезда КПСС и появления публикаций о гибели в советских тюрьмах и лагерях деятелей еврейской культуры те авторы и читатели газеты, которые не порвали с ней в середине 1950-х годов, сохраняли приверженность идеям коммунизма, но у многих из них вера в то, что эти идеи нашли претворение в СССР, пошатнулась. «Моргн-фрайхайт», всегда пристально следившая за развитием биробиджанского проекта, считала ошибочным утверждение Хрущева о провале плана создания полнокровной еврейской автономии на Дальнем Востоке по причине того, что евреи предпочитают заниматься интеллектуальной деятельностью и не желают подчиняться коллективной дисциплине. Редакция напомнила об успехе еврейских сельскохозяйственных колоний, существовавших до войны в Украине и Крыму, а также о том, что основной преградой для развития еврейской автономии стали репрессии 1930-х и 1940-х годов. Газета привела также примеры коллективизма евреев в Израиле, в американском рабочем движении и в героической борьбе против фашизма [Morgn-Frayhayt 1958, English page].

Интервью газете «Фигаро» не ускользнуло от внимания Джейкоба K. Джавица (Jacob K. Javits, 1904-1986), избранного в Сенат от штата НьюЙорк в 1956 г. Выросший в бедной семье еврейских иммигрантов, Джавиц в последующие годы играл важную роль в борьбе за гражданские права советских евреев. В ответ на слова Хрущева он заявил, что настало время приложить усилия для обеспечения беспрепятственного выезда евреев из CCCP [Ro’I 1991, 145-146]. Нахум Гольдман (Nahum Goldman, 1895-1982), президент Всемирной еврейской организации и Всемирного еврейского 
конгресса, с сарказмом предложил приветствовать слова Хрущева, усматривая в них признание того факта, что «евреи Советского Союза представляют собой нацию, отдельную и отличную от других наций Советского Союза, и [того,] что эта нация живет не в тех условиях, которые характерны для других наций в СССР». По его мнению, «признание этого, пусть даже в негативной форме, существенно для серьезного диалога о том, как решать проблему советских евреев» [Goldman 1958, 18]. Гольдман, естественно, видел решение в эмиграции в Израиль. Таким образом, слова Хрущева интерпретировались как убедительное свидетельство того, что евреев, имевших статус второсортных советских граждан, надо было срочно каким-то образом спасать.

Логично предположить, что статья о Еврейской автономной области (EAO), появившаяся в газете «Советская Россия» 6 августа 1958 г., должна была успокоить зарубежное общественное мнение. В Москве в это время гостил редактор «Моргн-фрайхайт» Пол (Пейсех) Новик (Paul Novick, 18911989). Ветеран социалистического и коммунистического движения, Новик родился и вырос в Бресте, хорошо владел русским языком. Как и многие другие представители зарубежных левых еврейских организаций, он приехал в СССР с целью понять, какую форму примет еврейская жизнь после «ликвидации последствий культа личности Сталина». Ознакомившись со статьей в «Советской России», Новик отправился в редакцию газеты, где надеялся встретиться с автором публикации В. Пахманом. Этого, однако, не случилось. Новику пришлось принять на веру объяснение, что Пахман не состоит в штате редакции и что вообще застать на месте его, перелетную птицу, очень трудно, поскольку основная его профессия - пилот гражданской авиации, а журналистикой он занимается в свободное время. Что касается замысла статьи, то якобы появился он у Пахмана после посещения Биробиджана (города без аэропорта) [Novick 1959a, 5].

Скорее всего, это была наспех сочиненная байка, пилота-журналиста вообще не существовало, а фамилия «Пахман» появилась под текстом, написанным и согласованным несколькими журналистами и работниками Центрального комитета КПСС. Был Пахман или не был, но статья, подписанная этим именем, стала первым за многие годы описанием ЕАО в центральной советской печати. В статье был сделан акцент на различии между счастливой жизнью биробиджанцев и горестями тех бывших жителей области, которые «под влиянием сионистской пропаганды» уехали в Израиль (несколько жителей Биробиджана, бывших польских граждан, переехали туда после репатриации в Польшу) [Shneiderman 1959, 2]. Однако еврейское государство, по утверждению «Советской России», встречало иммигрантов очень неприветливо, особенно если они были выходцами из Советского Союза, стран народной демократии и Индии. Иначе обстояло дело в ЕАО, где (в противоположность утверждению Хрущева) не случилось никакого провала проекта еврейской автономии. Евреи фигурировали в статье в раз- 
ных ролях: герои Советского Союза Иосиф Бумагин и Александр Кудрявицкий, погибшие в годы войны; секретарь горкома партии Иосиф Бокор; редактор местной еврейской газеты «Биробиджанер штерн» Наум Корчминский; еврейский писатель Бузи Миллер, чья книга («Под радугой») должна была вскоре выйти - и действительно вышла - в Москве в переводе на русский язык [Pinkus 1984, 382].

Так же внимательно, как и интервью Хрущева, зарубежные наблюдатели изучили статью Пахмана. Бенцион Гольдберг (Ben Zion Goldberg, 1895-1972), либеральный американский еврейский журналист и зять Шолом-Алейхема, пришел к заключению, что эта статья, перепечатанная или пересказанная просоветскими изданиями в разных странах, была «не просто еще одним газетным текстом». По его мнению, это был сигнал, указывавший на «новый поворот» в советской политике, на возврат к Биробиджану как к важному элементу пропаганды [Goldberg 1961, 215]. Гольдберг, в 1930-е и 1940-е годы считавшийся «другом Советского Союза», был опытным «биробиджановедом»: в 1934 г. он провел три недели в ЕАО и позже активно участвовал в кампаниях по сбору средств для этого проекта. Неудивительно, что он правильно почувствовал смену направления в пропагандистском использовании вестей из советско-еврейского Дальнего Востока.

\section{Слухи о переселении}

Были и другие интерпретации статьи в «Советской России». Журналист «Нью-Йорк таймс» Гарри Шварц (в советской печати его имя часто сопровождалось прилагательным «небезызвестный»), выучивший русский язык и часто писавший о Советском Союзе, обратил внимание на «разговоры в еврейских кругах» Америки о том, что «решение нарисовать яркую картину еврейской жизни в Биробиджане могло означать начало новой кампании, целью которой было бы побудить советских евреев переехать в эту область» [Schwartz 1958, 23].

Действительно, вскоре западные еврейские организации и периодические издания получили от израильских представителей «надежную информацию» о надвигающейся опасности для жизни советских евреев, связанной с тем, что советское правительство якобы рассматривало план их массового переселения в ЕАО. Более того, этот же источник утверждал, что такой план готовился для обсуждения и утверждения XXI съездом КПСС, заседания которого должны были начаться 27 января 1959 г. [Teller 1959, 4; Sanua 2007, 120]. Только люди со слабым пониманием реалий советской жизни могли предположить, что вопрос о переселении какой-то группы населения страны мог быть вынесен на «демократическое» обсуждение, особенно после публичного осуждения Хрущевым депортации различных 
народов в 1940-е годы. Внеочередной XXI съезд был созван не для решения «еврейского вопроса», а для консолидации власти Хрущева и принятия семилетнего плана развития народного хозяйства. При этом особое внимание уделялось усилению экономики Сибири. Такая повестка и могла послужить толчком к рассуждениям о возможном переселении евреев [Spiegel 1959a, 2].

При отсутствии независимой прессы и непроницаемости кремлевского закулисья слухи вообще играли важную роль в жизни страны и ее восприятии за рубежом [Зубкова 2000, 220-221; Johnston 2011, XI]. Например, в 1953 г. ходили упорные слухи о предстоящем выселении русских из Прибалтики [Зубкова 2004, 12]. Разговоры о переселении евреев в Биробиджан напоминали документально не подтвержденные слухи о депортации евреев, циркулировавшие в последние годы жизни Сталина и, по всей видимости, отражавшие не официальную политику, а настроение в обществе [Madievski, Cordes 1953, 561-568; Dobson 2003, 54; Костырченко 2003, 92-113; Winston 2015, 471-490]. Судя по письмам советских граждан (не евреев) в 1950-е годы какая-то часть населения приветствовала бы выселение евреев в восточные районы страны [Hopf 2012, 56; Dobson 2009, 29]. Тем не менее «достоверные источники» даже утверждали, что в марте 1953 г. Сталина довел до смерти апоплексический удар, случившийся, когда он пришел в ярость от того, что его ближайшие соратники отвергли план выселения евреев [Washington Post and Times Herald 1957, 4; Костырченко 2003, 98-99]. «Заслуживающие доверия свидетели» рассказывали, что в 1956 г., когда обсуждался вопрос о месте хранения урожая, собранного на целинных землях Средней Азии, кто-то якобы предложил использовать в качестве зернохранилищ оставшиеся невостребованными здания, построенные при подготовке к депортации 1952 года. Кроме того, говорили, что в ЕАО была направлена специальная комиссия, но нашла она там только развалины двух бараков, каждый длиной в два километра [AntonovOvseyenko 1980, 291]. Осенью 1956 г. утечка информации о советско-польских переговорах породила новый слух - о выселении евреев, которые были польскими и литовскими гражданами накануне Второй мировой войны [The New York Times 1956, 18]. На самом деле соглашение, подписанное в марте 1957 г., сделало возможной репатриацию бывших польских граждан, в том числе лиц еврейской национальности. В результате чего в 19571959 гг. около 20 тысяч евреев и членов их семей выехали из СССР, в большинстве своем они даже не планировали оставаться в Польше и переселились в Израиль [Skrzypek 1991, 66-74; Ruchniewicz 1999, 171-177; Вялікі 2007].

Новик указывал на статью в «Советской России» как свежий источник (точнее возбудитель) слухов, распространившихся в конце 1958 г. и начале 1959 г. [Novick 1959a]. В январе 1959 г. Хаим Словес (Haim Sloves, 1905-1988), французский еврейский писатель-коммунист, писал Морису Торезу: «Буржуазная пресса ряда стран недавно стала распространителем информации о так называемом плане «территориального решения», плане, кото- 
рый будет вынесен на обсуждение и в центре которого будет Биробиджан» [Aronowicz, Sloves 2002, 106]. Правда, не все наблюдатели поверили, что советское руководство имело в виду массовую депортацию. Более вероятной казалась им кампания, в ходе которой можно будет частично уговором, а частично принуждением заставить евреев, в первую очередь молодых людей, сорваться с места и «добровольно» переселиться на Дальний Восток [Crankshaw 1959, 10; The Jewish Observer 1959, 8]. Но даже такой более мягкий план вызывал разного рода опасения у западных еврейских деятелей. Перспектива укрепления ЕАО вряд ли могла быть по душе, например, тем, кто надеялся на эмиграцию советских евреев в Израиль.

\section{Встреча с Микояном}

15 января 1959 г. представители Американского еврейского комитета (AЕК), созданного в 1906 г. для противодействия погромам в России, встретились с Анастасом Микояном - Первым заместителем Председателя Совета Министров СССР и вообще одной из центральных фигур в окружении Хрущева. В Америку Микоян приехал на две недели в качестве гостя советского посла Михаила Меньшикова. Иными словами, с точки зрения протокола, это был неофициальный визит, в ходе которого Микояну пришлось часто «отвечать улыбками на оскорбления» во время встреч с представителями американской общественности [Windt 1971, 14]. Посольство США в Москве сообщало в Госдепартамент сведения о Микояне:

В свои 63 года Микоян незауряден в контексте как своего политического долголетия, так и экономической проницательности. Он пережил все крупнейшие политические потрясения со времен Гражданской войны без каких-либо последствий для себя, благодаря своей способности к присоединению к победившей стороне без того, чтобы быть замеченным в другой группе. Природное обаяние и юмор делают Микояна одним из наиболее способных советских переговорщиков. Он открыт и дружелюбен с иностранцами, и, кажется, больше заинтересован в усилении советского экономического могущества, чем в коммунистической идеологии [Неожиданный новогодний визит...].

Это была своеобразная разведка боем в ходе подготовки к историческому визиту Хрущева в сентябре этого же года. Серго Микоян (1929-2010), сопровождавший отца в поездке в США, вспоминал, что Хрущев поставил перед своим заместителем задачу улучшить отношения между странами, показать американцам, что у СССР нет агрессивных планов [Greiner 1990, 212]. Олег Трояновский (1919-2003), сын Александра Трояновского, первого советского посла в США, и позже тоже советский дипломат, выполнял роль помощника и переводчика. Ему эта поездка запомнилась своими труд- 
ностями - атмосфера все еще не разрядилась после военного вмешательства СССР в события в Венгрии в 1956 г. [Трояновский 2017, 197-198]. Напряжение было связано и с так называемым берлинским ультиматумом Хрущева (27 ноября 1958 г.), грозившим разрывом Потсдамского соглашения 1945 г.

AЕК не относился (и не относится) к категории массовых организаций. В его состав входили известные и состоятельные люди, не питавшие симпатий к Советскому Союзу. Тем не менее, Микоян и его советники приняли решение встретиться с четырьмя представителями этой влиятельной opганизации. В числе участников встречи были Герберт Лиман (Herbert Lehman, 1878-1973), банкир (сын одного из Lehman Brothers), бывший губернатор штата Нью-Йорк и член сената США, а также Джейкоб Блаустайн (Jacob Blaustein, 1892-1970), крупный предприниматель, дипломат и филантроп [Jewish Advocate 1959, 1; The American Israelite 1959, 1]. Другие американские еврейские организации, тоже пытавшиеся встретиться с советским представителем, остались недовольны тем, что АЕК монополизировал право говорить от имени всех евреев США [Yaffe 1959, 1].

Меморандум, подготовленный Юджином Хевеси (Eugene Hevesi, 18961983), секретарем по международным делам Американского еврейского комитета, позволяет понять, какое представление члены комитета имели о плане, «выявленном израильской разведкой в России» и конфиденциально пересказанном «официальными израильскими источниками»:

Израильтяне добавили еще одну деталь к своему сообщению, а именно, что советские власти могут применить образовательные и экономические «рычаги» для реализации плана переселения, избегая при этом использования административного принуждения. По этой причине израильтяне просили нас при публичном обсуждении этого вопроса не говорить о принудительных «массовых депортациях», так как любые допущенные нами преувеличения могут облегчить советской пропаганде решение задачи отрицания правдивости нашего заявления.

Между тем продолжают расти косвенные свидетельства, подтверждающие информацию, полученную от израильских правительственных кругов. После десятилетий молчания в советской прессе недавно вновь появились материалы, восхваляющие Биробиджан как еврейский «национальный дом». «Радио Каира» с большим удовлетворением приветствовало возрождение идеи «еврейской государственности» в Советском Союзе и высказало надежду, что господин Бен-Гурион тоже вскоре окажется в тех же краях. И последнее: 30 декабря передача украинского радио стала первым открытым проявлением антисемитизма с момента установления режима правления Хрущевым... [Except from memo... $]^{1}$

${ }^{1}$ Беспокойство вызвала передача кировоградского радио - см., например: Soviet Broadcast Incites against Jews in the Ukraine [The Sentinel 1959a]. 
В ходе продолжавшейся два часа беседы-ланча в манхетенской гостинице «Carlyle Hotel» Микоян полностью отрицал слухи о каком бы то ни было плане переселения евреев в ЕАО 2 . Американские участники встречи предложили Микояну подготовить по этому поводу официальное заявление. Вначале он отказывался это сделать, но затем согласился с тем, чтобы Лиман по итогам встречи заявил прессе об отсутствии оснований для появившихся сообщений о планируемом переселении евреев [The Jewish Chronicle 1959a, 13]. В ходе беседы речь шла не только о проблеме переселения. По инициативе американской стороны обсуждалось также состояние еврейской культурной и религиозной жизни. Было указано, что во всей стране, включая Биробиджан, не существует не только ни одной школы, но даже класса с преподаванием идиша или иврита [Spiegel 1959b, 1; Chicago Daily Tribune 1959, 3; Sanua 2007, 120].

Лондонская «The Jewish Chronicle» отметила в редакционной статье, что сам факт беседы Микояна с еврейскими деятелями накануне его встречи с президентом Дуайтом Д. Эйзенхауэром мог рассматриваться как свидетельство того, что советское правительство полностью осознало невозможность игнорирования реакции зарубежных общественных кругов на отношение к еврейскому населению страны. По мнению газеты, в результате американского визита Микояна можно было ожидать от советского руководства «большего благоразумия» в выборе решений в этой области [Тhe Jewish Chronicle 1959b, 16]. Важным было и то, что Ричард Никсон, в то время вице-президент США, «отозвался на просьбу американских евреев и смог убедить президента Эйзенхауера затронуть вопрос о советских евреях» во время встречи с Микояном [Rosenfeld 1971, 30].

\section{Итоги}

Историкам еще предстоит обнаружить архивные документы, связанные с подготовкой к XXI съезду КПСС (вдруг окажется, что кто-то действительно предлагал создать условия для привлечения евреев в ЕАО в ходе кампании по развитию Сибири и Дальнего Востока) и с визитом Микояна, особенно с неожиданно обрушившейся на него еврейской повесткой дня. Неопубликованным и пока еще недоступным остается отчет Микояна, а также отчеты советского посольства в США. Мы не знаем, когда и какие конкретно решения были приняты советским руководством. Тем не менее ясно, что частью этих решений стало возобновление публикаций на идише.

\footnotetext{
2 Любопытно, что в 1948 г. имя Микояна почему-то появилось на карте EAO, но после выхода в сентябре 1957 г. указа, запрещавшего наименование городов, улиц и т.п. в честь живых людей, поселок Микояновск получил новое название Хинганск.
} 
Первой книгой, напечатанной на идише в послесталинский период, стал сборник рассказов Шолом-Алейхема, подготовленный с удивительной скоростью - всего за две недели (вместо обычных пяти-шести месяцев) книга прошла все стадии от рукописи до появления в московских магазинах к столетнему юбилею классика еврейской литературы, отмечавшемуся 2 марта 1959 г. [The Sentinel 1959, 3; Novick 1959b, English page; Jews in Eastern Europe 1959, 24]. «The Jewish Chronicle» писала по этому поводу:

Хотя подготовка к столетию Шолом-Алейхема уже была к этому времени закончена, советское руководство предприняло беспрецедентные усилия для широчайшей популяризации этого события [т.е. публикации книги], особенно за рубежом. В адрес книжных магазинов Израиля и Соединенных Штатов поступили телеграммы о том, что они вскоре смогут получить напечатанный тиражом 30000 экземпляров сборник Шолом-Алейхема на идише.

В это же время советские посольства в Лондоне, Нью-Йорке [видимо, в Вашингтоне. - Г.Э.], Париже и еще в нескольких столицах распространили статью <...> Арона Вергелиса о влиянии Шолом-Алейхема в России и о том, как его произведения высоко ценятся во всех уголках Советского Союза ${ }^{3}$ <...>

Как и большинство мероприятий в Советском Союзе, публикация книги на идише и широкий размах чествования [столетия Шолом-Алейхема] не лишены политического значения. У советских властей была полная возможность убедиться в пристальном внимании евреев всего мира к проявлениям дискриминации по отношению к еврейскому меньшинству в СССР. <... Этот вопрос обсуждался во время недавней встречи господина Микояна и американских еврейских лидеров [The Jewish Chronicle 1959c, 36].

Борис Гершман (1917 - после 1991; автору этой статьи довелось работать с этим замечательным человеком в редакции журнала «Советиш геймланд») вспоминал, что его, корректора московского еврейского издательства «Дер эмес», закрытого в 1949 г., «просили помочь отыскать типографский еврейский шрифт».

Бывший корректор припомнил обрывки давних разговоров - о том, что при закрытии издательства «Дер эмес» шрифт вывезли, кажется, в типографию «Известий». Там, в подвале, он и был найден. Его разобрали, промыли бензином. Гершману пришлось набирать книгу, а затем вычитывать корректуру. Он рассказывал, как у него дрожали руки от волнения и страха, десять лет он не видел еврейского текста, позабыл правописание и боялся наделать ошибок [Резник 2005, 516].

\footnotetext{
${ }^{3}$ По всей вероятности, речь шла о статье А. Вергелиса «Шолом-Алейхем», напечатанной в «ИзвестияХ» 1 марта 1959 г. (С. 3).
} 
Сборник рассказов Шолом-Алейхема, вышедший в издательстве «Художественная литература» на фоне широкого празднования юбилея писателя [Эстрайх 2015, 188-214], открыл новую страницу в истории еврейского книгопечатания в СССР. В том же году это издательство выпустило книги еще двух классиков еврейской литературы - Менделе Мойхер-Сфорима и Ицхока-Лейбуша Переца.

С 1961 г. другое московское издательство - «Советский писатель» - стало играть ведущую роль в издании книг на идише: под маркой этого издательства Союза писателей СССР вышло большинство (251 из 277) книг, напечатанных в три последних советских десятилетия [Beider 2009, 68-69]. С этого же времени «Советский писатель» также печатал толстый журнал «Советиш геймланд» («Советская Родина») и фактически содержал его редакцию. В ожидании появления «на поверхности» новых архивных материалов можно предположить, что всему этому в какой-то мере способствовала и та цепная реакция, началом которой стали опрометчиво оброненные слова.

\section{Источники}

Известия 1958 - Беседа товарища Н.С. Хрущева с корреспондентом французской газеты «Фигаро» // Известия. 27 марта 1958.

Неожиданный новогодний визит... - Неожиданный новогодний визит Микояна в США. www.mediamax.am/ru/news/mikoyan/23427.

Трояновский 2017 - Трояновский О.A. Через годы и расстояния: история одной семьи. М., 2017.

Antonov-Ovseyenko 1980 - Antonov-Ovseyenko A. The Time of Stalin: Portrait of a Tyranny. New York, 1980.

Chicago Daily Tribune 1959 - Mikoyan Says Reds Plan no Jewish Colony // Chicago Daily Tribune. 16 January 1959.

Crankshaw 1959 - Crankshaw E. A New Exodus in the Air // The Observer. 11 January 1959.

Except from memo... - Except from memo by Eugene Henesi to Ralph Friedman, 2 January 1959. www.ajcarchives/AJC_DATA/Files/516.PDF.

Goldman 1958 - Goldman N. Khrushchev and the Soviet Jews // New York Herald Tribune. 7 May 1958.

Greiner 1990 - Greiner B. The Soviet View: An Interview with Sergo Mikoyan // Diplomatic History 14. 1990. № 2.

Hopf 2012 - Hopf T. Reconstructing the Cold War: The Early Years, 1945-58. New York, 2012.

Jewish Advocate 1959 - Mikoyan Bars Jews Visitors // Jewish Advocate. 15 January 1959. 
Jews in Eastern Europe 1959 - The Sholom Aleichem Centenary // Jews in Eastern Europe. 1959. № 1.

Morgn-Frayhayt 1958 - The Khrushchev Interview // Morgn-Frayhayt. 20 April 1958.

Novick 1959a - Novick P. Di Birobidzhan «propagande» in Moskve // MorgnFrayhayt. 20 February 1959.

Novick 1959b - Novick P. Volume of Sholom Aleichem's Works in Yiddish is to Appear in Moscow Soon // Morgn-Frayhayt. 23 February 1959.

Schwartz 1958 - Schwartz H. Moscow Depicts Birobidzhan Life // The New York Times. 31 August 1958.

Shneiderman 1959 - Shneiderman Sh.L. Tsvey yidn fun Biro-Bidzhan dertseyln zeyere iberlebungen // Forverts. 10 December 1959.

Spiegel 1959a - Spiegel I. Jews' Resettling by Soviet Is Seen: U.S. Group Says Moscow May Develop Birobidzhan Under 7-Year Plan // The New York Times. 11 January 1959.

Spiegel 1959b - Spiegel I. Mikoyan Denies Exiling of Jews // The New York Times. 16 January 1959.

Teller 1959 - Teller J. L. Exit of Jews to Siberia Hinted // The Christian Science Monitor. 5 January 1959.

The American Israelite 1959 - Mikoyan Denies Planned Exile of Jews to Siberia // The American Israelite. 22 January 1959.

The Jewish Chronicle 1959a - Mikoyan on Biro-Bidjan // The Jewish Chronicle. 23 January 1959.

The Jewish Chronicle 1959b - Soviet Attitudes // The Jewish Chronicle. 23 January 1959.

The Jewish Chronicle 1959c - Soviet Concessions // The Jewish Chronicle. 6 March 1959.

The Jewish Observer 1959 - The Jewish Observer: A Periodical Survey of Events Affecting Jews in the Soviet Bloc. 4 March 1959.

The New York Times 1956 - Soviet Deporting of Jews Reported // The New York Times. 9 November 1956.

The New York Times 1958 - Khrushchev Airs Analysis on Jews // The New York Times. 11 April 1958.

The Sentinel 1959a - Blasts Israel // The Sentinel. 8 January 1959.

The Sentinel 1959b - Soviet Plan to Begin Publishing Yiddish Writers after Ten Years // The Sentinel. 26 February 1959.

The Washington Post and Times Herald 1957 - French Paper Reports New Version of How Stalin Died in Rage over Jews // The Washington Post and Times Herald. 8 June 1957.

Windt 1971 - Windt Th.O. The Rhetoric of Peaceful Coexistence: Khrushchev in America, 1959 // The Quarterly Journal of Speech. Vol. 57. 1971. № 1.

Yaffe 1959 - Yaffe R. I Talk with the Kremlin // The Jewish Chronicle. 14 August 1959. 


\section{Литература}

Вялікі 2007 - Вялікі А.Ф. Беларусь-Польшча. Невядомая рэпатрыяцыя. 19551959 гг. ХХ ст. Минск, 2007.

Зубкова 2000 - Зубкова Е.Ю. Послевоенное советское общество. М., 2000.

Зубкова 2004 - Зубкова Е.Ю. «Власть» и развитие этноконфликтной ситуации в СССР, 1953-1985 гг. // Отечественная история. 2004. № 4. C. 3-32.

Константинов 2007 - Константинов В. Еврейское население бывшего СССР в XX веке. Иерусалим, 2007.

Костырченко 2003 - Костырченко Г.В. Депортация - мистификация: прощание с мифом сталинской эпохи // Отечественная история. 2003. № 1. C. 92-113.

Резник 2005 - Резник С.И. Вместе или врозь? Судьба евреев в СССР. Заметки на полях дилогии А.И. Солженицына. М., 2005.

Френкель 2016 - Френкель А.С. «Фрейд зол зайн!» - «Да будет радость!», или хождения по мукам ленинградской еврейской эстрады // Архив еврейской истории. Вып. 8. М., 2016. С. 305-339.

Эстрайх 2009 - Эстрайх Г. Разрешенная еврейская культура в послесталинскую «оттепель»: формирование модели // Идиш: язык и культура в Советском Союзе. М., 2009. С. 106-127.

Эстрайх 2015 - Эстрайх Г. Еврейская литературная жизнь Москвы, 19171991. СПб., 2015.

Aronowicz, Sloves 2002 - Aronowicz A., Sloves H. The Jewish People, and a Jewish Communist’s Allegiances // Jewish Social Studies. Vol. 9. 2002. № 1.

Dobson 2003 -Dobson M.J. Re-fashioning the Enemy: Popular Belifs and the Rhetoric of Destalinisation, 1953-1964. Ph. D. disseration. University College London, 2003.

Dobson 2009 - Dobson M. Khrushchev's Cold Summer: Gulag Returnees, Crime, and the Fate of Reform after Stalin. Ithaca, 2009.

Goldberg 1961 - Goldberg B.Z. The Jewish Problem in the Soviet Union: Analysis and Solution. New York, 1961.

Johnston 2011 - Johnston T. Being Soviet: Identity, Rumor, and Everyday Life under Stalin, 1939-1953. Oxford and New York, 2011.

Madievski, Cordes 1953 - Madievski S., Cordes Fr. 1953: La déportation des juifs soviétiques était-elle programmée? // Cahiers du Monde russe. Vol. 41. 2000. № 4. P. 561-568.

Norwood 2013 - Norwood St.H. Antisemitism and the American Far Left. New York, 2013.

Pinkus 1984 - Pinkus B. The Soviet Government and the Jews, 1948-1967: A Documented Study. Cambridge and New York, 1984.

Ro'i 1991 - Ro’i Y. The Struggle for Soviet Jewish Emigration, 1948-1967. New York, 1991. 
Rosenfeld 1979 - Rosenfeld S.S. Soviet Jews Draw New U.S. Attention: Prelude to Nixon Trip // The Washington Post. 19 November 1971.

Ruchniewicz 1999 - Ruchniewicz M. Tzw. repatriacja ludności polskiej z ZSRR w latach 1955-1959 // Dzieje Najnowsze. R. 31. 1999. № 2.

Sanua 2007 - Sanua M.R. Let Us Prove Strong: The American Jewish Committee. Hanover, NH, 2007.

Skrzypek 1991 - Skrzypek A. O drugiej repatriacji Polaków z ZSRR (1954-1959) // Kwartalnik Historyczny. R. 98. 1991. № 4.

Winston 2015 - Winston V.H. Reflections on the Anticipated Mass Deportation of Soviet Jews // Post-Soviet Affairs. Vol. 31. 2015. № 6.

\title{
Rumors about Expulsion to Birobidzhan, Anastas Mikoyan, and the American Jewish Establishment
}

\author{
Gennady Estraikh (New York University, USA; National Research University Higher School of \\ Economics, Moscow, Russia) \\ Professor, the Skirball Department of Hebrew and Judaic Studies, New York University, and \\ Leading Research Fellow at The International Centre for the History and Sociology of World \\ War II and Its Consequences, National Research University Higher School of Economics \\ E-mail:ge293@nyu.edu \\ ID ORCID: 0000-0002-7885-7851
}

Abstract: The events analyzed in this article took place in 1958 and 1959, when the situation around Birobidzhan became a cause of widespread anxiety among Jewish activists in the West. A rumor circulated that "the Soviet Jews appeared in peril of their lives", because the Soviet government was purportedly considering their mass forced resettlement to the Jewish Autonomous Region, in the Far East of Russia. In January 1959, representatives of the American Jewish Committee had a meeting with Anastas Mikoyan, the First Deputy Chairman of the Council of Ministers. He had come to the United States to hold preliminary talks before Nikita Khrushchev's historical visit in September 1959, and issues concerning the Jews were not on the agenda for his visit. However, after facing a barrage of questions about the alleged plan, he and his advisers decided that it would be unwise to avoid contact with representatives of the American Jewish establishment. The article draws attention to this meeting and the trace it left on the history of Soviet Jews.

Keywords: Birobidzhan, Mikoyan, Khrushchev, Antisemitism, Yiddish, Sholem Aleichem

DOI: 10.31168/2658-3364.2018.1.2.5 


\section{References}

Aronowicz A. Sloves H. The Jewish People, and a Jewish Communist's Allegiances // Jewish Social Studies. Vol. 9. 2002. № 1.

Dobson M. Khrushchev's Cold Summer: Gulag Returnees, Crime, and the Fate of Reform after Stalin. Ithaca, 2009.

Estraikh G. Razreshennaia evreiskaia kul'tura v poslestalinskuiu “ottepel"”: formirovanie modeli // Idish: iazyk i kul'tura v Sovetskom Soiuze. Moscow, 2009.

Estraikh G. Evreiskaia literaturnaia zhizn' Moskvy, 1917-1991. St. Petersburg, 2015.

Frenkel A.S. “Freid zol zain!” - “da budet radost'!”, ili khozhdeniia po mukam leningradskoi evreiskoi estrady // Arkhiv evreiskoi istorii. Iss. 8. Moscow, 2016.

Goldberg B.Z. The Jewish Problem in the Soviet Union: Analysis and Solution. New York, 1961.

Johnston T. Being Soviet: Identity, Rumor, and Everyday Life under Stalin, 19391953. Oxford; New York, 2011.

Konstantinov V. Evreiskoe naselenie byvshego SSSR v XX veke. Jerusalem, 2007.

Kostyrchenko G.V. Deportatsiia - mistifikatsiia: proshchanie s mifom stalinskoi epokhi // Otechestvennaia istoriia. 2003. No. 1.

Madievski S., Cordes Fr. La déportation des juifs soviétiques était-elle programmée? 1953 // Cahiers du Monde russe. Vol. 41. 2000. № 4.

Norwood St.H. Antisemitism and the American Left. New York, 2013.

Pinkus B. The Soviet Government and the Jews, 1948-1967: A Documented Study. Cambridge; New York, 1984.

Reznik S.I. Vmeste ili vroz'? Sud'ba evreev v SSSR. Zametki na poliakh dilogii A.I. Solzhenitsyna. Moscow, 2005.

Ro'I Y. The Struggle for Soviet Jewish Emigration, 1948-1967. New York, 1991.

Rosenfeld S.S. Soviet Jews Draw New U.S. Attention: Prelude to Nixon Trip // The Washington Post. 19 November 1971.

Ruchniewicz M. Tzw. repatriacja ludności polskiej z ZSRR w latach 1955-1959 // Dzieje Najnowsze. R. 31. 1999. № 2.

Sanua M.R. Let Us Prove Strong: The American Jewish Committee. Hanover (NH), 2007.

Skrzypek A. O drugiej repatriacji Polaków z ZSRR (1954-1959) // Kwartalnik Historyczny. R. 98. 1991. № 4.

Winston V.H. Reflections on the Anticipated Mass Deportation of Soviet Jews // Post-Soviet Affairs. Vol. 31. 2015. № 6.

Zubkova E.Yu. Poslevoennoe sovetskoe obshchestvo. Moscow, 2000.

Zubkova E.Yu. "Vlast"” i razvitie etnokonfliktnoi situatsii v SSSR, 1953-1985 gg. // Otechestvennaia istoriia. 2004. No. 4. 